\title{
Interannual variation of soil respiration in a beech forest ecosystem over a six-year study
}

\author{
Daniel EPRON ${ }^{\mathrm{a}, \mathrm{b} *}$, Jérome $_{\mathrm{NGAO}}^{\mathrm{c}}$, André GRANIER $^{\mathrm{c}}$ \\ ${ }^{a}$ Laboratoire de Biologie et Écophysiologie, Université de Franche-Comté, Pôle Universitaire, BP 71427, 25211 Montbéliard Cedex, France \\ b Current address: Université Henri Poincaré - UMR 1137 INRA UHP, Écologie et Écophysiologie forestières, BP 239, \\ 54506 Vandœuvre-les-Nancy Cedex, France \\ c UMR INRA UHP Écologie et Écophysiologie Forestières, Centre INRA de Nancy, 54280 Champenoux, France
}

(Received 3 March 2003; accepted 29 September 2003)

\begin{abstract}
Soil respiration was measured for six years from June 1996 to December 2001 in order to investigate both seasonal and interannual variations in a young beech forest in North Eastern France (Hesse forest). Soil respiration exhibited pronounced seasonal variations that clearly followed the seasonal changes in soil temperature $(T)$ and soil water content $(W)$. An exponential function $\left(y=A W e^{B T}\right)$ fitted the data well, and including a linear effect of soil water content on soil respiration strongly improved the predictive capacity of the model. However, the increase in residuals when plotted against the date of measurements clearly evidenced that changes in soil temperature or soil water content failed to predict the increase in soil respiration with time, highlighting that the interannual variation in soil respiration was not solely due to direct climate effects. When fitted against single year data, the temperature sensitivity coefficient $(B)$ was very close for both years while the pre-exponential factor $(A)$ for 1997 was half of those for 2001. The model was further run over the entire data set, allowing $A$ to vary from one year to another. There was a close agreement between predicted and observed soil respiration and $A$ exhibited a linear trend with time with a high value for 1999 after thinning.
\end{abstract}

carbon flux / beech / soil respiration / interannual variability / thinning / Fagus sylvatica

Résumé - Variation interannuelle de la respiration du sol dans une hêtraie au cours de six années de mesure. La respiration du sol a été mesurée pendant six années de juin 1996 à décembre 2001 pour analyser les variations saisonnières et interannuelles dans une jeune hêtraie du nord-est de la France (forêt de Hesse). La respiration du sol montrait des variations saisonnières marquées, reflétant clairement les changements saisonniers de la température $(T)$ et du contenu en eau du sol $(W)$. Une fonction exponentielle $\left(y=A W e^{B T}\right)$ s'ajustait correctement sur les données, et le fait d'inclure un effet linéaire du contenu en eau du sol augmentait considérablement les capacités prédictives du modèle. Néanmoins, l'augmentation des résidus lorsqu'ils étaient tracés en fonction de la date de mesure montrait clairement que les changements de température et de contenu en eau du sol ne permettaient pas de prédire les variations de respiration du sol au cours du temps, soulignant le fait que les variations interannuelles de la respiration du sol n'étaient pas uniquement dues à des effets directs du climat. Lorsqu'ils étaient ajustés sur les données d'une seule année, le coefficient de sensibilité à la température $(B)$ était très proche pour les deux années de mesures alors que le facteur pré-exponentiel (A) était deux fois plus faible en 1997 qu'en 2001. Lorsque le modèle est appliqué sur l'ensemble du jeu de données, en permettant à $A$ de varier d'une année sur l'autre, la respiration prédite était très proche de la respiration mesurée, et $A$ montrait une augmentation linéaire avec le temps, avec une valeur élevée en 1999 après une éclaircie.

flux de carbone / hêtre / respiration du sol / variabilité interannuelle / éclaircie / Fagus sylvatica

\section{INTRODUCTION}

Carbon sequestration in forested ecosystems often results from a small difference between photosynthetic carbon fixation and ecosystem respiration $[15,38]$, and soil respiration is the main component of ecosystem respiration [15, 21].

Soil respiration is known to exhibit a high spatial and temporal variability. Spatial heterogeneity of soil respiration has often been described and related to either root biomass, microbial biomass, litter amount, soil characteristics or site topography $[13,16,41]$. Seasonal variations of soil respiration were often associated with either changes in soil temperature $[1,8$, $12,13,26]$ or changes in both soil temperature and soil water content $[5,9,14,16,22,32,41]$.

Up to now, only a few numbers of studies have deal with the interannual variability of soil respiration. Interannual variations

\footnotetext{
* Corresponding author: Daniel.Epron@ scbiol.uhp-nancy.fr
} 
in soil respiration may result from direct effects of environmental factors like soil temperature or soil water content that could exhibit year to year variations. Indeed, occurrence of a summer drought can account for a reduced soil respiration [2, 9, 35, 40]. Alternatively, changes in ecosystem processes due to long-term climate effects, forest ageing or disturbance might also account for interannual variations in soil respiration. Indeed, it has recently been shown that summer carbon efflux has doubled over a quarter century in four forest ecosystems in the southern Appalachians [4]. Long lasting measurement series are still required to improve our ability to scale up measurements made over a limited period to provide a meaningful description of the long-term dynamics of soil carbon.

This paper presents the results obtained after six years of measurements in a young beech stand. Soil respiration was measured from June 1996 to December 2001, together with soil temperature and soil water content. In a previous paper [9], we showed that soil respiration exhibited pronounced seasonal variations, which did not solely reflect seasonal changes in soil temperature. Especially, strong differences in soil respiration between summer 1996 and summer 1997 were at least partly explained by an inhibition of soil respiration at low soil water content. The objective was now to investigate both seasonal and interannual variability of soil respiration. The ability of an empirical model using soil temperature and soil water content as driving variables to predict both seasonal and interannual changes in soil respiration was evaluated. Changes in model parameters between years would highlight the contribution of changes in ecosystem characteristics on the interannual variability of soil respiration.

\section{MATERIALS AND METHODS}

\subsection{Site characteristics}

The experimental plot (Carboeuroflux site) covers 0.6 ha and is located in the central part of a 65 ha zone in the state forest of Hesse (France, $48^{\circ} 40^{\prime} \mathrm{N}, 7^{\circ} 05^{\prime} \mathrm{E}$, elevation $300 \mathrm{~m}$ ). It is dominated by beech (Fagus sylvatica). Other tree species are Carpinus betulus, Betula alba, Fraxinus excelsior, Prunus avium, Quercus petraea, Larix decidua. The understorey vegetation is very sparse. The plot was thinned during winter 1994/1995 and during winter 1998/1999 as shown by huge changes in leaf area index (Tab. I). Trees were about 30 year-old at the beginning of the measurements in 1996. Low values of ground area are characteristic of young, frequently thinned plots. Variations of stand and climate characteristics during the six years of measurements are given in Table I. Soil is a gleyic luvisol according to the F.A.O. classification (clay $22 \%$, loam $70 \%$ and sand $8 \%$ ). The $\mathrm{pH}$ of the top soil $(0-30 \mathrm{~cm})$ is 4.9 with a $\mathrm{C} / \mathrm{N}$ of 12.2 and an apparent density of $0.85 \mathrm{~kg} \mathrm{dm}^{-3}$. Water holding capacity was about $0.40 \mathrm{~m}^{3} \mathrm{~m}^{-3}$. Mineral soil is covered with mull type humus. Six sub-plots of about $100 \mathrm{~m}^{2}$ each were randomly chosen within the experimental plot for soil respiration measurements [9].

\subsection{Measurements of soil respiration}

Soil respiration was measured using the Li 6000-09 (LiCor Inc, Lincoln, NE, USA) soil respiration chamber in which the increase of the $\mathrm{CO}_{2}$ concentration was recorded with the $\mathrm{Li} 6250$ infrared gas analyser (LiCor Inc) as already described $[9,10]$. The chamber edge is inserted in the soil to a depth of $1.5 \mathrm{~cm}$. The $\mathrm{CO}_{2}$ concentration within the soil respiration chamber was dropped $15 \mu \mathrm{mol} \mathrm{mol}^{-1}$ below ambient, and the increase in the $\mathrm{CO}_{2}$ concentration was recorded until it raised by $30 \mu \mathrm{mol} \mathrm{mol}^{-1}$. For each day of measurements, twelve records were done in each sub-plot, leading to a total of 72 measurements collected over the experimental plot during a 8-hour period from 8 am to $4 \mathrm{pm}$. This high number of samples allowed the confidence intervals of the mean at $p=0.05$ to be within $10 \%$ of the mean despite a large spatial variability. Measurements were initiated in June 1996 and were continued until December 2001. Measurements frequency was not constant over the whole six-year period. Soil respiration data were collected from June to November 1996 (5 days), from January to November in 1997 (16 days), in April, June, August and October 1998 (4 days), in March, April, June, August and October 1999 (5 days), in April and August 2000 ( 2 days) and from March to December in 2001 (9 days). The same operator using the same protocol did measurements during the whole period with the same equipment. The gas analyser was calibrated before each sampling days with $\mathrm{CO}_{2}$ free air and a $393 \mu \mathrm{mol} \mathrm{mol}^{-1} \mathrm{CO}_{2}( \pm 2 \%$ ) certified standard (Alpha gaz, Air Liquide, France).

\subsection{Measurements of soil temperature and soil water content}

Soil temperature was monitored simultaneously with soil respiration using a copper/constantan thermocouple penetration probe (Li6000$09 \mathrm{TC}, \mathrm{LiCor}$ Inc) inserted in the soil to a depth of $10 \mathrm{~cm}$ in the vicinity of the soil respiration chamber. Volumetric water content of the soil at $10 \mathrm{~cm}$ depth was measured with a neutron probe (NEA, Denmark) in 8 aluminium access tubes at 1 -week to 3 -week intervals. A polyethylene reflector and specific calibration curve were used for these sub-surface measurements.

\subsection{Data analysis}

Daily means of soil respiration, soil water content and soil temperature were used for examining seasonal and interannual trends. Nonlinear regression were performed with statview 5 (SAS Institute inc. NC, USA) using either an exponential function $\left(R=A \mathrm{e}^{B T}\right)$, an Arrhenius function $\left(R=A \mathrm{e}^{-B / T}\right)$ or a power function $\left(R=A T^{B}\right)$. These models were fitted through soil respiration $(R)$ and soil temperature $(T)$. These models were also fitted using soil water content $(W)$ rather than soil temperature alone to account for a linear decrease in soil respiration with decreasing soil water content. Indeed, it has already been shown that soil respiration was best predicted when soil water content was included in the model $\left(R=A W \mathrm{e}^{B T}\right.$, [9] $)$. These models were first fitted on the whole data set. Criteria for a valid model were a maximum coefficient of determination $\left(r^{2}\right)$, a minimum root mean squared error (RMSE) and no bias in the distribution of the residues. This latter point was assessed by testing the nullity of the slope of the regression between residuals and soil temperature. The exponential function was selected (see results) and it was further fitted on single year data for 1997 and 2001. There were enough observations for these two years to support separate analyses. Finally, the exponential model was fitted using non-linear least square regression curves (Sigma Plot 4.1, SPPS Inc., IL, USA) over the entire data set, allowing the pre-exponential factor to vary from year to year $\left(A_{Y}, Y\right.$ varying from 1996 to 2001). This was achieved by adding a dummy variable $\left(D_{Y}\right)$ coded 1 for year $\mathrm{Y}$ and coded 0 for other years $\left(R=\Sigma A_{Y} W D_{Y} \mathrm{e}^{B T}\right)$. Mean values of soil respiration and models parameters are given with their standard error.

\section{RESULTS}

Soil respiration exhibited pronounced seasonal variations with minimal values in winter and high values in early summer 
Table I. Stand and climate characteristics of the Hesse forest during the six years of measurements.

\begin{tabular}{|c|c|c|c|c|c|c|}
\hline & 1996 & 1997 & 1998 & 1999 & 2000 & 2001 \\
\hline $\operatorname{LAI}\left(\mathrm{m}^{2} \mathrm{~m}^{-2}\right)^{\mathrm{a}}$ & 5.7 & 5.59 & 7.36 & 4.84 & 7.33 & 7.37 \\
\hline Stand density (stems ha ${ }^{-1}$ ) & 4589 & 4428 & 4445 & 3331 & 3263 & 3178 \\
\hline Ground area $\left(\mathrm{m}^{2} \mathrm{ha}^{-1}\right)$ & 19.2 & 20.6 & 22.4 & 18.1 & 19.3 & 20.4 \\
\hline Average tree height (m) & 12.7 & & & & & 14.0 \\
\hline Average stem diameter $(\mathrm{cm})$ & 21.3 & 22.1 & 23.0 & 23.6 & 24.6 & 25.7 \\
\hline Average air temperature $\left({ }^{\circ} \mathrm{C}\right)$ & 9.06 & 9.77 & 9.72 & 10.14 & 10.86 & 10.10 \\
\hline Average soil temperature $\left({ }^{\circ} \mathrm{C}\right)$ & 8.81 & 9.55 & 9.37 & 10.11 & 10.30 & 9.87 \\
\hline Cumulative annual rainfall (mm) & 560 & 730 & 828 & 903 & 887 & 770 \\
\hline Cumulative summer rainfall $(\mathrm{mm})$ & 285 & 391 & 378 & 460 & 525 & 480 \\
\hline
\end{tabular}

a Estimated from litterfall collections.
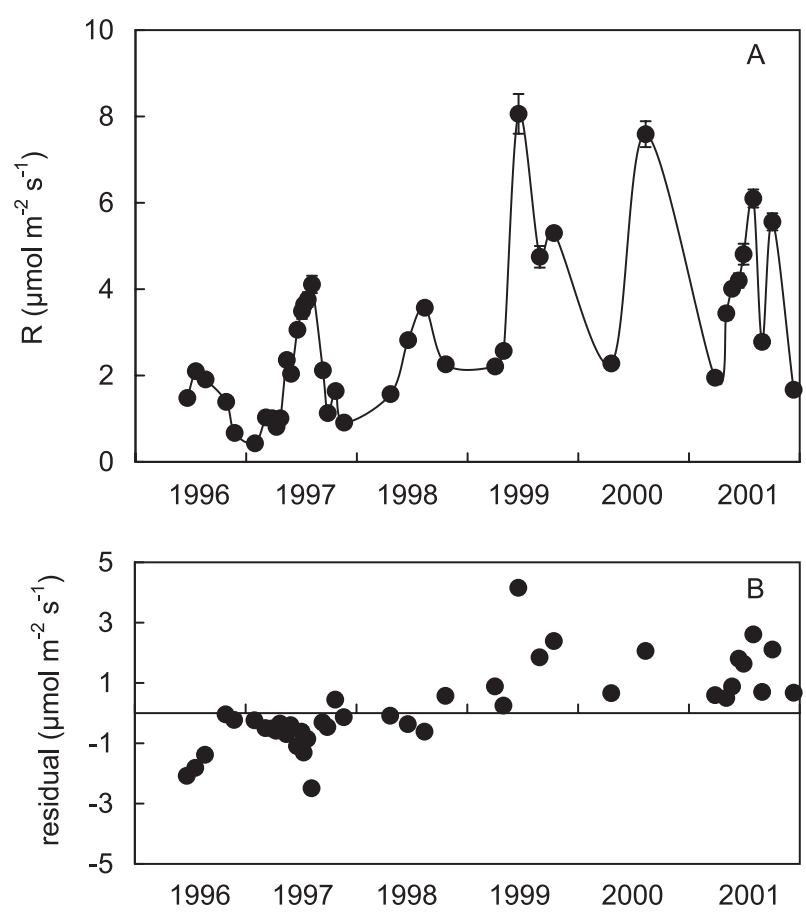

Figure 1. Soil respiration (A) and residual error term of predicted soil respiration using an exponential model (B) as a function of time. Vertical bars, when larger than the symbol, indicate the standard error of the mean of soil respiration $(n=72)$.

(Fig. 1). Soil respiration rates were low during the three first years (1996-1998), ranging from $0.4 \mu \mathrm{mol} \mathrm{m}^{-2} \mathrm{~s}^{-1}$ in February 1997 to $4.1 \mu \mathrm{mol} \mathrm{m} \mathrm{s}^{-1}$ during August 1997. In contrast, higher soil respiration rates were recorded during the three following years (1999-2001) with a maximal rate and a minimal rate of 8.1 and $1.7 \mu \mathrm{mol} \mathrm{m} \mathrm{m}^{-2} \mathrm{~s}^{-1}$ respectively.

These year-to-year differences in soil respiration were highlighted when 1997 data are compared with 2001 data (Fig. 2). Seasonal courses of soil respiration clearly followed the seasonal changes in soil temperature and low soil water content due to low rainfalls resulted in lower soil respiration rate in late summer than in early summer. Soil temperature followed a similar
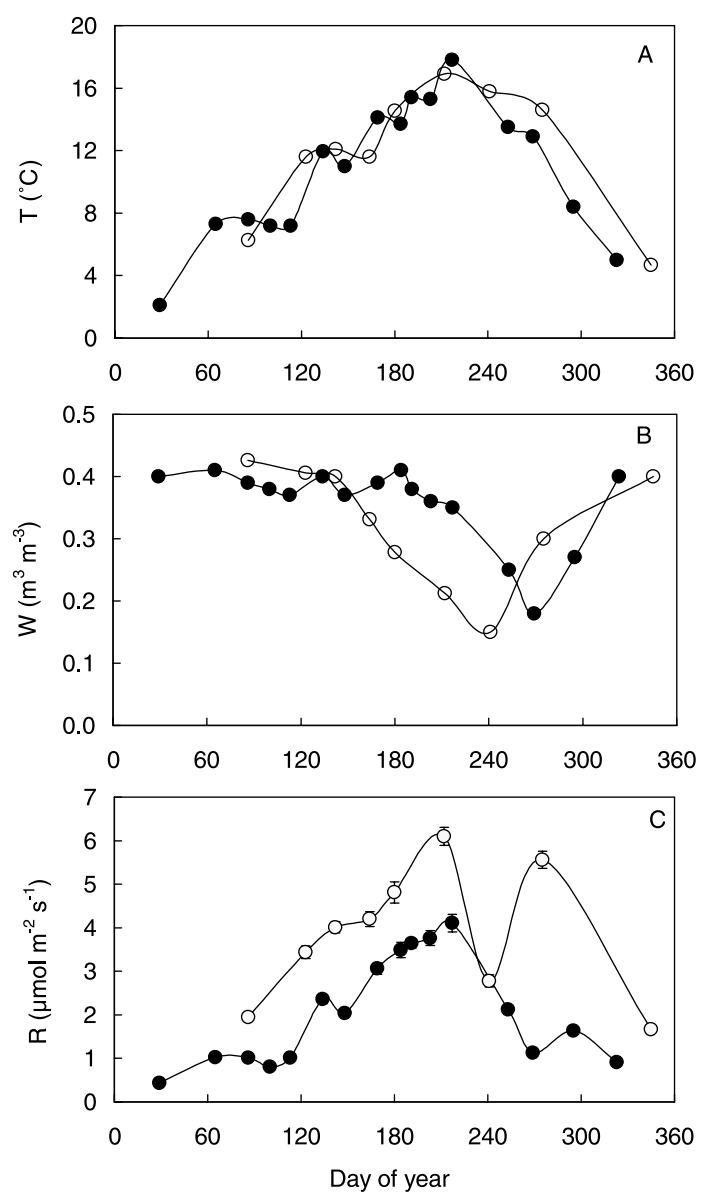

Figure 2. Seasonal courses of (A) daily mean soil temperature $(T)$ at $10 \mathrm{~cm}$ depth, (B) mean soil volumetric water content $(W)$ in the top $10 \mathrm{~cm}$ and $(C)$ mean soil respiration $(R)$ for 1997 (closed symbols) and 2001 (open symbols). Vertical bars, when larger than the symbol, indicate the standard error of the mean of soil respiration $(n=72)$.

cycle for both years and the annual means of daily soil temperature at $10-\mathrm{cm}$ depth in 2001 was $0.4{ }^{\circ} \mathrm{C}$ higher than in 1997. In contrast, soil water content decreased earlier in 2001 than in 
Table II. Predicted model parameters $(A, B)$, determination coefficients $\left(r^{2}\right)$, root mean squared error (RMSE) and the slope of model residuals versus soil temperature for empirical models describing the relationship between soil respiration $(R)$ and either soil temperature at $10 \mathrm{~cm}$ depth $(T)$ or soil temperature and soil water content in the top $10 \mathrm{~cm}(W)$.

\begin{tabular}{|c|c|c|c|c|c|c|}
\hline Function & Equation & $A$ & $B$ & $r^{2}$ & RMSE & Slope \\
\hline Exponential & $\begin{array}{l}R=A e^{B T} \\
R=A W e^{B T}\end{array}$ & $\begin{array}{l}0.588 \\
1.206\end{array}$ & $\begin{array}{l}0.121 \\
0.155\end{array}$ & $\begin{array}{l}0.56 \\
0.72\end{array}$ & $\begin{array}{l}1.46 \\
1.34\end{array}$ & $\begin{array}{l}-0.004 \\
-0.001\end{array}$ \\
\hline Arrhenius & $\begin{array}{l}R=A e^{-B / T} \\
R=A W e^{-B / T}\end{array}$ & $\begin{array}{l}1.9010^{15} \\
7.8110^{19}\end{array}$ & $\begin{array}{l}9.7710^{3} \\
1.2510^{4}\end{array}$ & $\begin{array}{l}0.56 \\
0.72\end{array}$ & $\begin{array}{l}1.46 \\
1.34\end{array}$ & $\begin{array}{l}-0.003 \\
-0.001\end{array}$ \\
\hline Power & $\begin{array}{l}R=A T^{B} \\
R=A W T^{B}\end{array}$ & $\begin{array}{l}0.170 \\
0.273\end{array}$ & $\begin{array}{l}1.117 \\
1.384\end{array}$ & $\begin{array}{l}0.59 \\
0.71\end{array}$ & $\begin{array}{l}1.41 \\
1.33\end{array}$ & $\begin{array}{l}0.033 \\
0.050\end{array}$ \\
\hline
\end{tabular}

$p$-values were below 0.001 for all non linear regressions $(n=41)$.
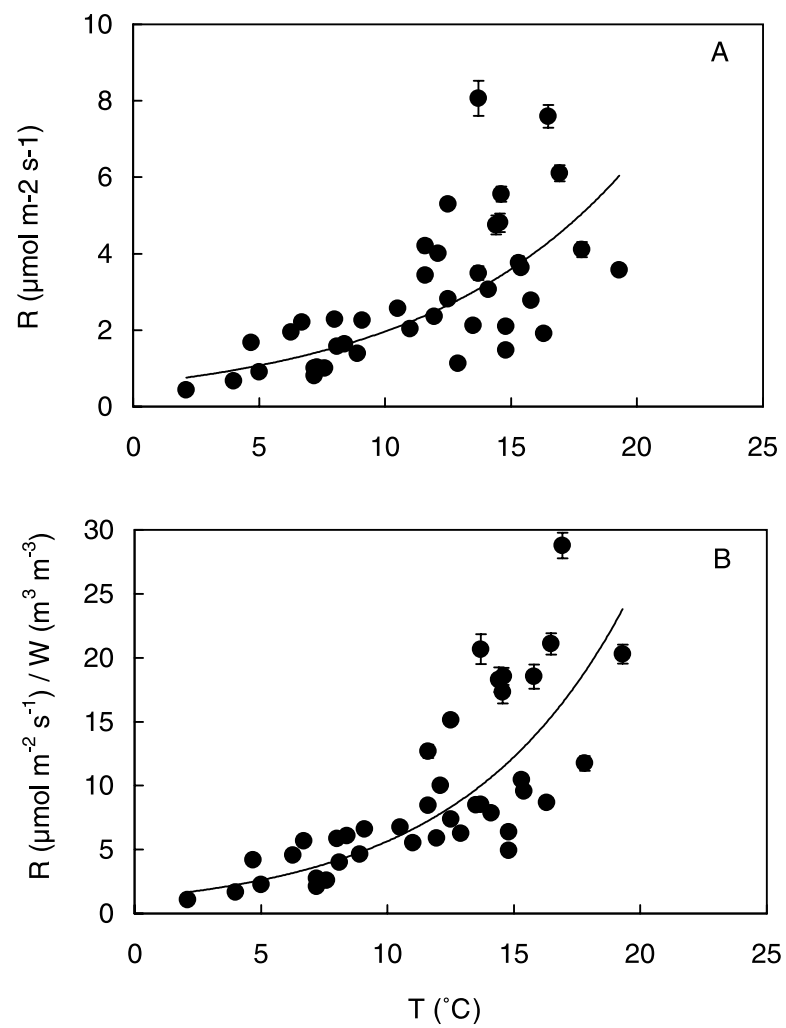

Figure 3. Relationship (A) between daily mean soil respiration $(R)$ and mean soil temperature $(T)$ at a depth of $10 \mathrm{~cm}$ and $(B)$ between the ratio of mean soil respiration and mean soil volumetric water content in the top $10 \mathrm{~cm}(R / W) . R / W$ is an algebraic manipulation of the model $R=A W \mathrm{e}^{B T}$ allowing a two-dimension representation of the data. Data are from Figure 1. Lines are the best fit of an exponential function ( $r^{2}$ values were 0.56 in $A$ and 0.72 in $\left.B, n=41, p<0.001\right)$.

1997 due to lower rainfalls in early summer. Soil water content reached similar minimal values below $0.2 \mathrm{~m}^{3} \mathrm{~m}^{-3}$ during both summers. As a consequence, soil respiration followed a similar trend until the end of July (day 210), but with higher rates in 2001 than in 1997. Large discrepancies in August and early September can be ascribed to the earlier drought in 2001.

Exponential, power and Arrhenius-type functions were fitted over the entire set of data, using soil temperature as a driving variable and either soil respiration or the ratio of soil respiration

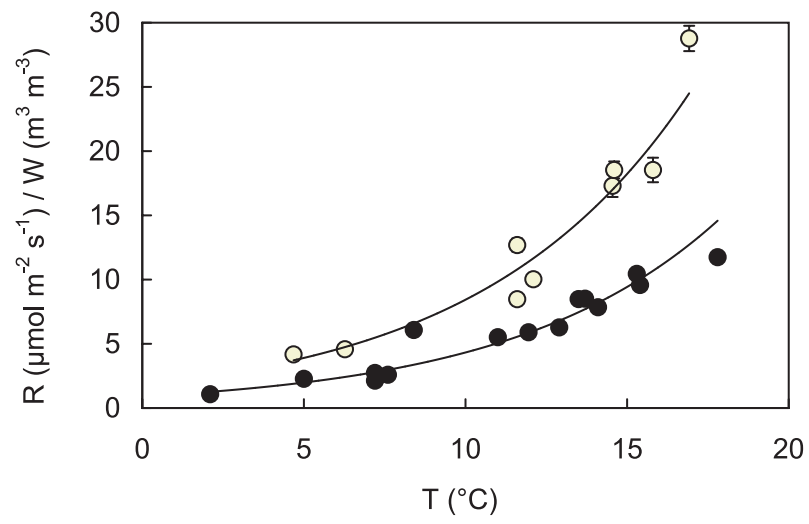

Figure 4. Relationship between the ratio daily mean soil respiration and mean soil volumetric water content in the top $10 \mathrm{~cm}(R / W)$ and mean soil temperature $(T)$ at a depth of $10 \mathrm{~cm}$ for 1997 (closed symbols) and 2001 (open symbols). Data are from Figure 2. The line is the best fit of an exponential function $\left(r^{2}=0.92, n=16, p<0.001\right.$ in 1997 and $r^{2}=0.95, n=9, p<0.001$ in 2001).

over soil water content as dependent variables (see Fig. 3 for the exponential one). The three function fitted the data well and including a linear effect of soil water content on soil respiration strongly improved the predictive capacity of the three kind of model ( $r^{2}$ increased from $0.56-0.59$ to $071-0.72$, Tab. II). Analysis of residual (slope of the regression between residuals and soil temperature) showed that the power function tend to overestimate soil respiration at high temperature and to underestimate soil respiration at low temperature. Both the Arrhenius function and the exponential function seem to provide an unbiased estimate of soil respiration. However, when the residuals of these models were plotted against the date of measurements (Fig. 1 for the exponential function), the observed increase in residuals clearly evidenced that changes in soil temperature or soil water content failed to predict the increase in soil respiration with time. Residuals during the 1999-2001 period were all positive while most of them were negative before that period. However, a linear trend was already evident during the 19961999 period, while no clear trend was observed later.

When plotted against single year data, the model $\left(y=A W \mathrm{e}^{B T}\right)$ fitted the data very well with $r^{2}$ values of 0.92 in 1997 and 0.95 in 2001 (Fig. 4). The temperature sensitivity coefficient $(B)$ was very close for both years $(0.154 \pm 0.012$ and $0.156 \pm 0.013$ for 

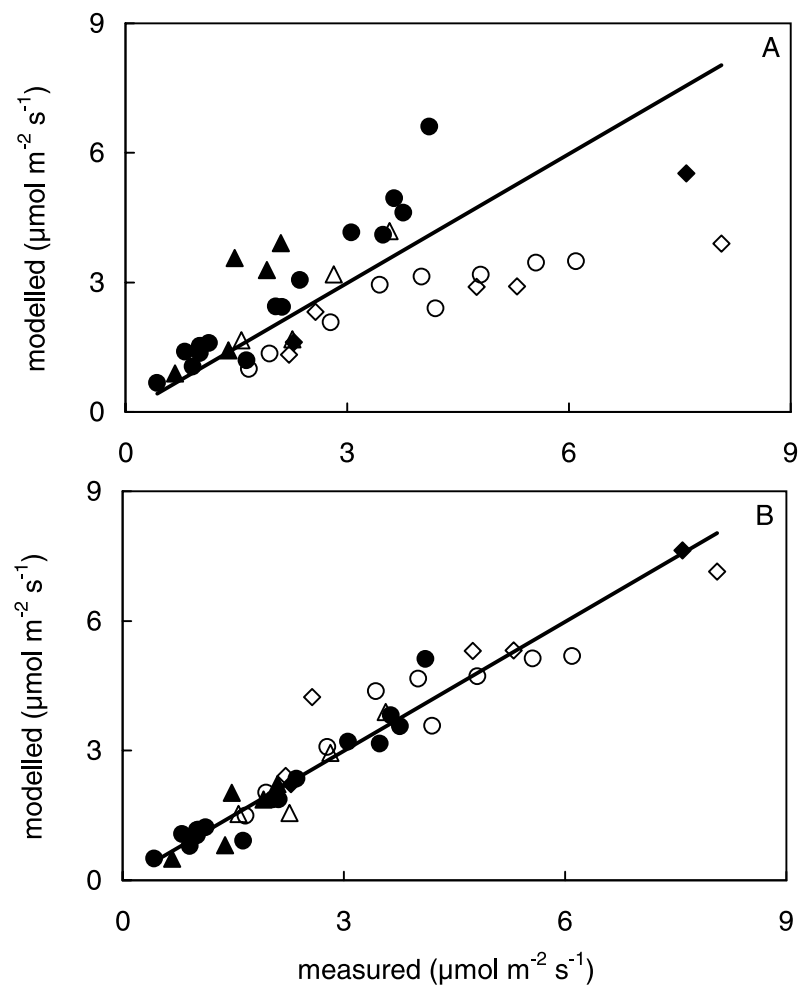

Figure 5. Relationship between measured and predicted values of soil respiration $(R)$ with an exponential function $\left(R=A W \mathrm{e}^{B T}\right)$ with $T$ the temperature of the soil at a depth of $10 \mathrm{~cm}$ and $W$ the soil volumetric water content in the top $10 \mathrm{~cm}$, (A) using a single pre exponential factor for all years or (B) using an adjusted pre exponential factor for each year (closed triangles, 1996; closed circles, 1997; open triangles, 1998; open diamonds, 1999; close diamonds, 2000; open circles). Values of $r^{2}$ were 0.72 in A and 0.93 in B $(n=41$, $p<0.001)$.

1997 and 2001 respectively). In contrast, the pre-exponential factor $(A)$ has doubled from 1997 to 2001 (0.91 and 1.81 respectively), and their $95 \%$ confidence intervals did not overlap (upper limit for 1997 and lower limit for 2001 being respectively 1.21 and 1.23 ).

There were not enough points for the four other years for fitting the exponential function ( 2 to 5 days of measurements only). Taking advantage of a very similar $B$ values in 1997 and 2001, the model was run over the entire data set, adjusting a single $B$ value for all years $(0.158 \pm 0.009)$, but allowing the pre exponential factor to vary from one year to another. There was a close agreement between predicted and observed soil respiration $\left(r^{2}=0.93\right.$, RMSE $\left.=0.38\right)$ which was better than those observed using a single $A$ value for all years $\left(r^{2}=0.72\right.$, RMSE $=$ 1.34), as shown in Figure 5. Interestingly, the pre-exponential factor $(A)$ exhibited a linear trend with time with a high value for 1999 after thinning (Fig. 6).

\section{DISCUSSION}

Exponential relationships have frequently and successfully been used to predict soil respiration from soil temperature [3,

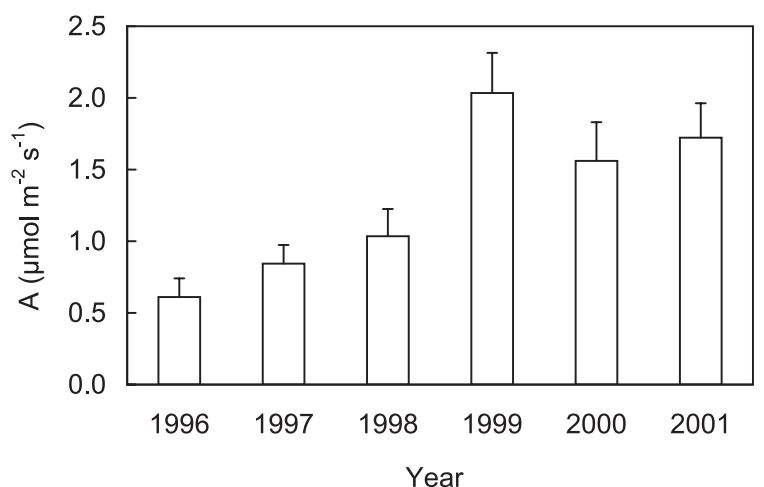

Figure 6. Predicted values of the pre-exponential factor (A) for each year computed from an exponential function $\left(R=A W \mathrm{e}^{B T}\right.$, see Fig. 5B) describing the relationship between soil respiration $(R)$ and soil temperature at $10 \mathrm{~cm}$ depth $(T)$ and soil water content in the top $10 \mathrm{~cm}(W)$.

$5,9]$. It has been reported that an exponential function would systematically lead to underestimated fluxes at low temperatures and overestimated fluxes at high temperatures, and suggested that soil respiration was better described by an Arrhenius-type relationships [25]. In this study, all models fit reasonably well with the data and the exponential one was chosen thereafter. Several functions are available to describe the effects of soil water content on soil respiration $[11,16,20,22]$. In this site, including a linear effect of soil water content in the function used to predict soil respiration from soil temperature greatly enhance the predictive efficiency of the model, as already shown [9]. Using more complex models would have unnecessarily increased the number of model parameters without a significant gain in the explained variance. The $B$ values obtained on single year data (1997 and 2001), and on the whole data set with either a single or a variable pre-exponential factor, were almost similar and corresponds to a $Q_{10}$ value of 4.7-4.8 $\left(Q_{10}=\right.$ $\left.\mathrm{e}^{10 \mathrm{~B}}\right)$. This is a rather high value that is however within the range of published values for temperate forest ecosystems [2, $5,9]$. Indeed, the temperature sensitivity coefficient is though to reflect both a direct sensitivity of the involved processes as well as the change in size and activity of the respiring components (i.e. root and microbial biomass) because the exponential function was fitted over a large period of time. Growth of root and microbial population occurred in late spring and early summer and their effects on soil respiration are therefore confounded with the increase in soil temperature.

Seasonal changes of soil respiration can be well predicted with our simple exponential model when fitted on single year data [9]. The doubling in the pre-exponential factor between 1997 and 2001 highlighted the contribution of changes in some ecosystem characteristics on the interannual variability of soil respiration that was not solely due to direct climate effects that would have been taken into account in the model.

Interannual changes in soil respiration have already been reported in forest ecosystem. Soil respiration increased by about $50 \%$ between two adjacent years in boreal forest regenerations after a clearcut $[30,39]$. Most of the time, these yearto-year variations in soil respiration were ascribed to difference 
in soil water content during summer months $[19,35]$. Similar drought-induced decreases in soil respiration were reported for beech, spruce and pine stands in one forest in Germany while strong increase in soil respiration seemed independent of soil water content in other beech and pines [2]. In Hesse forest, soil respiration difference between 1996 and 1997 was also first ascribed to difference in summer rainfalls [9] while there is now some evidence that others causes are likely to account for these year-to-year differences in soil respiration.

When the exponential model was fitted over the six years periods, a close agreement between predicted and observed soil respiration was obtained if the pre-exponential factor was allowed to change from year to year. Even if the size of the data set for the four other years limits the strength of year-to-year comparison, one should recognised that the difference observed between 1997 and 2001 was not fortuitous. Indeed, the preexponential factor clearly exhibited a linear trend from $0.61 \pm$ 0.13 in 1996 to $1.72 \pm 0.24$ in 2001 with an average increase of about $0.2 \mu \mathrm{mol} \mathrm{m}{ }^{-2} \mathrm{~s}^{-1}$ per year, except in 1999. A doubling of summer soil respiration was also observed in four stands in the southern Appalachians that was not directly related to climatic factors, but these changes were operated across a long span of 23-25 years [3]. More recently, it was showed that the interannual variations in ecosystem respiration cannot be fully explained by direct effects of climatic factors in the pine plantation in the Duke forest, and was ascribed to some "functional changes" [18]. Temporal changes in the basal respiration rates in the current experiment may be due to the increment in root and microbial biomass. Indeed, the experimental plot was located in a young, actively growing, beech stand, and stand biomass increased by about $10 \%$ each year (unpublished data). An increase in soil respiration in a young slash pine plantation has been ascribed to an increase in root biomass with age [12], while ageing did not influence soil respiration of replanted cut block in a sub-boreal forest [31]. Indirect effects of climate that would affect phenology, photosynthesis or reserve constitution are unlikely to fully account for the gradual increase of soil respiration with age but it should not be excluded in the present study because the first years and summers were drier than the last ones. Indeed, a multiple regression with the pre-exponential factor as dependent variable and average soil temperature and summer precipitation as independent variables explains $67 \%$ (adjusted $R^{2}, p=0.090$ ) of the interannual variability in soil respiration. Thus, a climatic effect might also contribute to the interannual variability of soil respiration, either directly or through an effect on annual productivity, which is related to soil respiration [21].

Separating ageing phenomenon from the confounding effects of thinning was impossible because the plot was thinned during winter 1994/1995 and during winter 1998/1999. However, excessively high soil respiration rates were observed in 1999. Previous published data did not concerned thinning but clear cutting, and showed either an increase [12,27], a decrease [36, 39], stability [29,37], or an increase followed by a decrease in soil respiration [7]. Partial or total tree removal is thought to increase soil respiration because more light reaching the soil would increase soil temperature and reduced transpiration would increase soil humidity. In addition to these climatic effects, decrease in root biomass and increase in root necromass would decrease the root component of soil respiration and would increase the microbial component. About one fifth of the ground area were removed by thinning. According to allometric equations that were established before thinning [23], coarse root biomass was decreased from $0.35 \mathrm{~kg}_{\mathrm{DM} \mathrm{m}} \mathrm{m}^{-2}$ while coarse root necromass was similarly increased. Using 1997 estimates of fine root biomass [10] the amount of fine root that were transferred from the lived to the dead compartments was about $0.15 \mathrm{~kg}_{\mathrm{DM} \mathrm{m}} \mathrm{m}^{-2}$. The time courses of these transfers are unknown, as stored carbohydrate within roots would support their survival for some time following thinning. It could take some years for the largest roots. The increase in soil respiration after thinning would suggest that the decrease in root respiration would be more than compensated by the enhanced microbial respiration. A putative explanation would be that suppressed competition for water and nutrient by thinning, and increased rooting space, will stimulate coarse root branching and elongation of the remaining trees, and fine root proliferation. Indeed, reduced competition for water after thinning increased lateral root growth in young Pinus radiata [28]. Therefore, thinning-induced root proliferation would compensate for the initial decrease in root biomass, maintaining the contribution of root respiration during the following years.

The fitted function was not used to estimate the annual soil carbon flux for each year because the pre-exponential factor was obtained from a limited number of observations for four of the six years of measurements. In addition, measurements were never carried during rainy days while post-rainfall respiration burst have frequently been described [6, 17, 24, 33, 34].

The ecosystem processes that are behind these interannual variations of soil respiration are probably complex, and causal mechanisms would probably be difficult to assess, but these results highlighted the need of long term records of soil fluxes for parameterizing and validating soil carbon exchange model at the ecosystem level.

Acknowledgements: This work were supported by the European programs Euroflux (ENV4-CT95-0078) and Carboeuroflux (EVK2-CT1999-00032). The "Communauté d'Agglomération du Pays de Montbéliard" (CAPM) is also acknowledged for financial supports. The two anonymous reviewers are thanked for their valuable comments.

\section{REFERENCES}

[1] Anderson J.M., Carbon dioxide evolution from two temperate, deciduous woodland soils, J. Appl. Ecol. 10 (1973) 361-378.

[2] Borken W., Xu Y.J., Davidson E.A., Beese F., Site and temporal variation of soil respiration in European beech, Norway spruce and Scots pine forests, Glob. Change Biol. 8 (2002) 1205-1216.

[3] Buchmann N., Kao W.Y., Ehleringer J.R., Carbon dioxide concentrations within forest canopies - variation with time, stand structure, and vegetation type, Glob. Change Biol. 2 (2000) 421-432.

[4] Coleman D.C., Hunter M.D., Hutton J., Pomeroy S., Swift L. Jr., Soil respiration from four aggrading forested watersheds measured over a quarter century, For. Ecol. Manage. 157 (2002) 247-253.

[5] Davidson E.A., Beck E., Boone R.D., Soil water content and temperature as independent or confounded factors controlling soil respiration in a temperate mixed hardwood forest, Glob. Change Biol. 4 (1998) 217-227.

[6] Davidson E.A., Verchot L.V., Cattânio J.H., Ackerman I.L., Carvalho J.E.M., Effects of soil water content on soil respiration in forests 
and cattle pastures of eastern Amazonia, Biogeochemistry 48 (2000) 53-69.

[7] Edwards N.T., Ross-Todd B.M., Soil carbon dynamics in a mixed deciduous forest following clear-cutting with and without residue removal, Soil Sci. Soc. Amer. J. 47 (1983) 1014-1021.

[8] Edwards N.T., Effects of temperature and moisture on carbon dioxide evolution in a mixed deciduous forest floor, Soil Sci. Soc. Amer. J. 39 (1975) 361-365.

[9] Epron D., Farque L., Lucot E., Badot P.M., Soil $\mathrm{CO}_{2}$ efflux in a beech forest: dependence on soil temperature and soil water content, Ann. For. Sci. 56 (1999) 221-226.

[10] Epron D., Farque L., Lucot E., Badot P.M., Soil $\mathrm{CO}_{2}$ efflux in a beech forest: the contribution of root respiration. Ann. For. Sci. 56 (1999) 289-295.

[11] Epron D., Nouvellon Y., Roupsard O., Mouvondy W., Mabiala A., Saint André L., Joffre R., Jourdan C., Bonnefond J.M., Berbigier P., Hamel O., Spatial and temporal variation of soil respiration in a Eucalyptus plantation in Congo, For. Ecol. Manage. (2004) under press.

[12] Ewel K.C., Cropper W.P., Gholz H.L., Soil $\mathrm{CO}_{2}$ evolution in Florida slash pine plantations. I. Changes through time, Can. J. For. Res. 17 (1987) 325-329.

[13] Fang C., Moncrieff J.B., Gholz H.L., Clark K.L., Soil $\mathrm{CO}_{2}$ efflux and its spatial variation in a Florida slash pine plantation, Plant Soil 205 (1998) 135-146.

[14] Garret H.E., Cox G.S., Carbon dioxide evolution from the floor of an oak-hickory forest, Soil Sci. Soc. Amer. Proc. 37 (1973) 641-644.

[15] Granier A., Ceschia E., Damesin C., Dufrêne E., Epron D., Gross P., Lebaube S., Le Dantec V., Le Goff N., Lemoine D., Lucot E., Ottorini J.M., Pontailler J.Y., Saugier B., The carbon balance of a young beech forest, Funct. Ecol. 14 (2000) 312-325.

[16] Hanson P.J., Wullschleger S.D., Bohlman S.A., Todd D.E., Seasonal and topographic patterns of forest floor $\mathrm{CO}_{2}$ efflux from an upland oak forest, Tree Physiol. 13 (1993) 1-15.

[17] Holt J.A., Hodgen M.J., Lamb D., Soil respiration in the seasonally dry tropics near Townville, North Queensland, Aust. J. Soil Res. 28 (1990) 737-745.

[18] Hui D., Luo Y., Katul G., Partitioning interannual variability in net ecosystem exchange between climatic variability and functional change, Tree Physiol. 23 (2003) 433-442.

[19] Irvine J., Law B.E., Contrasting soil respiration in young and oldgrowth ponderosa pine forests, Glob. Change Biol. 8 (2002) 1183 1194.

[20] Janssens I.A., Dore S., Epron D., Lankreijer H., Buchmann N., Longdoz B., Brossaud J., Montagnani L., Climatic influence on seasonal and spatial differences in soil $\mathrm{CO}_{2}$ efflux, in: Valentini R. (Ed.), Fluxes of carbon, water and energy of European forests, Springer-Verlag, Berlin, Heidelberg, New York, 2003, pp. 233-253.

[21] Janssens I.A., Lankreijer H., Metteucci G., Kowalski A.S., Buchmann N., Epron D., Pilegaard K., Kutsch W., Longdoz B., Grünwald T., Montagnani L., Dore S., Rebmann C., Moors E.J., Grelle A., Rannik Ü., Morgenstern K., Olchev S., Clement R., Gudmundsson J., Minerbi S., Berbigier P., Ibrom A., Moncrieff J., Aubinet M., Bernhofer C., Jensen N.O., Vesala T., Granier A., Schulze E.D., Lindroth A., Dolman A.J., Jarvis P.G., Ceulemans R., Valentini R., Productivity overshadows temperature in determining soil and ecosystem respiration across European forests, Glob. Change Biol. 7 (2001) 269-278.

[22] Joffre R., Ourcival J.M., Rambal S., Rocheteau A., The key-role of topsoil moisture on $\mathrm{CO}_{2}$ efflux from a mediterranean Quercus ilex forest, Ann. For. Sci. 60 (2003) 519-526.

[23] Le Goff N., Ottorini J.M., Root biomass and biomass increment in a beech (Fagus sylvatica L.) stand in Northeast of France, Ann. For. Sci. 58 (2001) 1-13.
[24] Liu X., Wan S., Su B., Hui D., Luo Y., Response of soil $\mathrm{CO}_{2}$ efflux to water manipulation in a tallgrass prairie ecosystem, Plant Soil 240 (2002) 213-223.

[25] Lloyd J., Taylor J.A., On the temperature dependence of soil respiration, Funct. Ecol. 8 (1994) 315-323.

[26] Longdoz B., Yernaux M., Aubinet M., Soil $\mathrm{CO}_{2}$ efflux measurements in a mixed forest: impact of chamber disturbances, spatial variability and seasonal evolution, Glob. Change Biol. 6 (2000) 907-917.

[27] Lytle D.E., Cronan C.S., Comparative soil $\mathrm{CO}_{2}$ evolution, litter decay, and root dynamics in clearcut and uncut spruce-fir forest, For. Ecol. Manage. 103 (1998) 121-128.

[28] Gautam M.K., Mead D.J., Clinton P.W., Chang S.X., Biomass and morphology of Pinus radiata coarse root components in a subhumid temperate silvopastoral system, For. Ecol. Manage. 177 (2003) 387-397.

[29] Marra J.L., Edmonds R.L., Coarse woody debris and soil respiration in a clearcut on the Olympic Peninsula, Washington, USA, Can. J. For. Res. (1996) 1337-1345.

[30] Pypker T.G., Fredeen A.L., Ecosystem $\mathrm{CO}_{2}$ flux over two growing seasons for a sub-Boreal clearcut 5 and 6 years after harvest, Agricult. For. Meteorol. 114 (2002) 15-30.

[31] Pypker T.G., Fredeen A.L., Below ground $\mathrm{CO}_{2}$ efflux from cut blocks of varying ages in sub-Boreal British Columbia, For. Ecol. Manage. 172 (2003) 246-259.

[32] Qi Y., Xu M., Separating the effects of moisture and temperature on soil $\mathrm{CO}_{2}$ efflux in a coniferous forest in the Sierra Nevada mountains, Plant Soil 237 (2001) 15-23.

[33] Rey A., Pegoraro E., Tedeschi V., De Parri I., Jarvis P., Valentini R., Annual variation in soil respiration and its components in a coppice oak forest in central Italy, Glob. Change Biol. 8 (2002) 851866.

[34] Rochette P., Desjardins R.L., Pattey E., Spatial and temporal variability of soil respiration in agricultural fields, Can. J. Soil Sci. 71 (1991) 189-196.

[35] Savage K.E., Davidson E.A., Interannual variation of soil respiration in two New England forests, Glob. Biogeochem. Cycles 15 (2001) 337-350.

[36] Striegl R.G., Wickland K.P., Effects of a clear-cut harvest on soil respiration in a jack pine-lichen woodland, Can. J. For. Res. 28 (1998) 534-539.

[37] Toland D.E., Zak D.R., Seasonal patterns of soil respiration in intact and clear-cut northern hardwood forests, Can. J. For. Res. 24 (1994) 1711-1716.

[38] Valentini R., Matteucci G., Dolman A.J., Schulze E.D., Rebmann C., Moors E.J., Granier A., Gross P., Jensen N.O., Pilegaard K., Lindroth A., Grelle A., Bernhofer C., Grünwald T., Aubinet M., Ceulemans R., Kowalski A.S., Vesala T., Rannik Ü., Berbigier P., Lousteau D., Gudmundsson J., Thorgeirsson H., Ibrom A., Morgenstern K., Clement R., Moncrieff J., Montagnani L., Minerbi S., Jarvis P.G., Respiration as the main determinant of European forests carbon balance, Nature 404 (2000) 861-865.

[39] Weber M.G., Forest soil respiration after cutting and burning in immature aspen ecosystems, For. Ecol. Manage. 31 (1990) 1-14.

[40] Wilson K.B., Baldocchi D.D., Comparing independent estimates of carbon dioxide exchange over 5 years at a deciduous forest in the southeastern United States, J. Geophys. Res. 106 (2001) 3416734178.

[41] Xu M., Qi Y., Soil-surface $\mathrm{CO}_{2}$ efflux and its spatial and temporal variations in a young ponderosa pine plantation in northern California, Glob. Change Biol. 7 (2001) 667-677. 